\title{
Kajian Penggunaan Biourine Sapi dan Ekstrak Bawang Merah Terhadap Sifat Agronomi Tanaman Kubis (Brasicca oleracea L.) Dataran Rendah
}

\section{Study of the Use of Cattle Biourine and Shallot Extract on the Agronomic Properties of Cabbage Plants (Brasicca oleracea L.) Lowlands}

\author{
Tutik Nugrahini $^{1}$, Asiah Wati ${ }^{2}$, Dwi Indriani ${ }^{3}$
}

\author{
${ }^{1}$ Tenaga Pendidik Program Studi Agroteknologi, Fakultas Pertanian, Universitas Widya Gama Mahakam \\ Jl. KH. Wahid Hasyim, Sempaja, Samarinda, Kalimantan Timur, Indonesia \\ ${ }^{1}$ Tenaga Kependidikan Program Studi Agroteknologi, Fakultas Pertanian, Universitas Widya Gama Mahakam \\ Jl. KH. Wahid Hasyim, Sempaja, Samarinda, Kalimantan Timur, Indonesia \\ ${ }^{3}$ Alumni Program Studi Agroteknologi, Fakultas Pertanian, Universitas Widya Gama Mahakam \\ Jl. KH. Wahid Hasyim, Sempaja, Samarinda, Kalimantan Timur, Indonesia
}

Email : tutik.nugrahini@gmail.com, asiahwati@uwgm.ac.id,dwi_indriani96@yahoo.com

Diterima : 21 Agustus 2018 Disetujui : 12 Oktober 2018

\begin{abstract}
Cabbage (Brasicca oleracea L.) is one type of vegetable plant from the Brassicaceae family. This plant is a source of nutrients that contain nutrients, vitamins, minerals and fiber for the human body. And has economic value. Cabbage cultivation is influenced by the types of cultivated varieties that are in accordance with growing conditions. In general, cabbage plants grow on highlands. Along with advances in plant breeding technology, cabbage plants are available that can adapt to the lowlands and technically attempt to increase production by fertilizing. The study aimed to determine the effect of beef biourine, red onion extract and beef biourine and red onion extract on the agronomic properties of cabbage plants. The study was conducted for 4 months, from February to June 2018. The location of the study was carried out in the Sempaja Timur Village, Samarinda City, East Kalimantan Province. cabbage seeds, top soil, manure, husks, NPK fertilizer, cow urine, empon-empon, soybeans, brown sugar, shallots. The design used in this study is Factorial Randomized Block Design (RBD) with 2 treatments. The first treatment was beef biourine $(S)$ with 4 levels, namely with 3 replications: sO: control (water), s1: $25 \%$ concentration of cow biourine, s2: $75 \%$ concentration of bovine biourine, s3: 100\% concentration of bovine biourine and second treatment red onion extract $(B)$ with 4 levels, namely: b0: control (water), b1: 25\% concentration of red onion extract, b2: 75\% concentration of red onion extract, b3: 100\% concentration of shallot extract. The results of research on bovine biourine influenced plant height, number of leaves at ages 7, 14, 21, 28.35 and 42 days after planting. The weight of the crop with the best results at the level of b2 (75\% biourine cow) weighing 596.58 grams, onion extract affects plant height, number of leaves at 7, 14, 21, 28.35 and 42 hst, crop weight with the best results at the $m 2$ level (75\% red onion extract) with a weight of 567.14 grams and the interaction of the treatment of beef biourine and shallots affects plant height, number of leaves at the ages of 7, 14, 21, 28.35 and 42 days and days formed at the level b2m2 (75\% beef biourine and 75 red onion extracts).
\end{abstract}

Keywords: cabbage, beef biourine, shallot extract

\section{PENDAHULUAN}

Kubis (Brasicca oleracea L.) merupakan salah satu jenis tanaman sayur-sayuran dari famili Brassicaceae. Tanaman ini menjadi sumber nutrisi yang mengandung gizi, vitamin, mineral dan serat bagi tubuh manusia. Serta memiliki nilai ekonomis (Erwin, 2015). Menurut data Badan Pusat Statistik Kalimantan Timur (BPS, 2017) bahwa produksi tanaman kubis di Samarinda pada tahun 2011 sampai dengan 2015 mengalami penurunan yang drastis 260 ton per tahun sampai dengan 4 ton per tahun.

Penurunan produksi ternama dapat dipengaruhi oleh teknologi budidaya yang kurang tepat berupa pemilihan benih varietas maupun pemeliharaan khususnya pemupukan yang tidak tepat. Penanaman kubis yang tidak sesuai varietas terhadap syarat tumbuh akan menurunkan produksi (Sunarjono, 2013).

Budidaya tanaman kubis dipengaruhi jenis varietas yang dibudidayakan yang sesuai dengan syarat tumbuh. Pada umumnya tanaman kubis tumbuh pada dataran tinggi. Seiring dengan kemajuan teknologi pemuliaan tanaman telah tersedia tanaman kubis yang dapat beradaptasi pada dataran rendah (Badan Penelitian dan Pengembangan Penelitian Kementerian Pertanian, 2015).

Pemupukan merupakan upaya penambahan unsur hara berupa pupuk yang menggantikan unsur hara yang habis diserap oleh tanaman. Upaya pemupukan dapat menghasilkan hasil yang optimal bila dilakukan dengan tepat. 
Pemupukan dilakukan dengan konsentrasi dan waktu pemupukan yang tepat akan menghasilkan produksi yang optimal (Lingga dan Marsono, 2013).

Pemberian pupuk pada tanaman berupa pupuk organik dan pupuk anorganik. Biourine sapi merupakan salah satu pupuk organik yang dapat digunakan pada tanaman. Penggunaan biourine sapi meningkatkan berat segar kailan sebesar 46,65\% (Puspita, 2015) ditambahkan oleh Yuliarta (2014) penggunaan biourine sapi dapat meningkatkan hasil $42,59 \%$ tanaman selada krop sebelum menggunakan biourine sapi.

Selain penggunaan pupuk upaya peningkatan hasil tanaman dan ditambahkan zat pengatur tumbuh alami ataupun buatan. Ekstrak bawang merah merupakan zat pengatur tumbuh yang mampu meningkatkan pertumbuhan tinggi dan jumlah daun pada tanaman sawi (Syfandy, 2017). Pemberian ekstrak bawang merah mempengaruhi umur berbunga dan meningkatkan jumlah polong pada tanaman kedelai (Purwati, 2017). Berdasarkan uraian di atas maka perlu dilakukan penelitian kajian penggunaan biourine sapi dan ekstrak bawang merah terhadap sifat agronomi tanaman kubis (Brasicca oleracea L.) Dataran Rendah.

\section{BAHAN DAN METODE}

Penelitian dilaksanakan selama 4 bulan, terhitung bulan Februari - Juni 2018. Lokasi penelitian dilaksanakan di Kelurahan Sempaja Timur Kota Samarinda Provinsi Kalimanta Timur. Bahan yang digunakan dalam penelitian ini ; benih kubis, top soil, pupuk kandang, sekam, pupuk NPK, urine sapi, empon-empon, kedelai, gula merah, bawang merah. Rancangan yang digunakan dipenelitian ini Rancangan Acak Kelompok (RAK) Faktorial dengan 2 perlakuan. Perlakuan pertama yaitu biourine sapi (S) dengan 4 taraf yaitu dengan 3 ulangan : s0 : kontrol (air), s1: 25\% konsentrasi biourine sapi, s2 : 75\% konsentrasi biourine sapi, s3: 100\% konsentrasi biourine sapi dan perlakuan kedua yaitu ekstrak bawang merah (B) dengan 4 taraf yaitu : b0 : kontrol (air), b1: 25\% konsentrasi ekstrak bawang merah, b2 : 75\% konsentrasi ekstrak bawang merah, b3: 100\% konsentrasi ekstrak bawang merah. Pelaksanaan penelitian meliputi : penyiapan media tanam, persemaian, penanaman, pemeliharaan meliputi penyulaman, penyiraman, pengendalian organisme pengganggu tanaman dan panen. Pengambilan data meliputi : tinggi tanaman, jumlah daun, hari terbentuk krop, berat krop, diameter krop. Data analisis dengan menggunakan sidik ragam, apabil terdapat pengaruh pada sidik ragam maka dilakukan uji BNT pada taraf 5\%.

\section{HASIL DAN PEMBAHASAN}

Hasil analisis tanah dilaboratorium tanah universitas Mulawarman dan kreteria Kisaran Kelas Kesuburan Kimiawi Tanah Diadopsi dari FAO 1986 (Yusrani dan Subroto, 2005) menunjukkan bahwa tanah yang digunakan sebagai media tanam mempunyai $\mathrm{pH}$ sangat asam $(4,13)$, C-Organik sangat rendah $(0,90 \%)$, $\mathrm{N}$-Total sangat rendah $(0,08 \%), \mathrm{C} / \mathrm{N}$ rasio sedang (11), $\mathrm{P}_{2} \mathrm{O}_{5}$ sangat rendah (2,96 ppm), $\mathrm{K}_{2} \mathrm{O}$ sedang (40,9 ppm), $\mathrm{Al}^{3+}$ tinggi $(4,58$ meq/100g), $\mathrm{H}^{+}$tinggi $(3,22 \mathrm{meq} / 100 \mathrm{~g}), \mathrm{Ca}^{++}$ sangat rendah $(2,32 \mathrm{meq} / 100 \mathrm{~g}), \mathrm{Mg}^{++}$sangat tinggi $(2,08 \mathrm{meq} / 100 \mathrm{~g}), \mathrm{K}^{+}$rendah $(0,22$ meq $/ 100 \mathrm{~g}), \mathrm{Na}^{+}$rendah $(0,15 \mathrm{meq} / 100 \mathrm{~g})$, KTK sedang $(23,7 \mathrm{meq} / 100 \mathrm{~g})$, kejenuhan basa sangat rendah (20\%) dan kejenuhan Al tinggi (49\%). Hasil analisis kimia biourine sapi $\mathrm{N}$ total $0,5240 \%$, P total $0,0197 \%$ dan $\mathrm{K} 0,978 \%$ dan $\mathrm{pH} 7,81$ dari hasil laboratorium tanah dan air Politeknik Pertanian Negeri Samarinda. Hasil analisis ekstrak bawang merah IAA 3,8254 ppm , Giberelin 85,2083 ppm dan Kinetin 21, 8178 ppm dari hasil analisis SUA Usaha jasa dan Industri Biofutur Depatemen Biologi, FMIPA, IPB.

Tabel 1. Rata-Rata Tinggi Tanaman Umur 7 HST Pada Perlakuan Biourine Sapi (B), Ekstrak Bawang Merah (M) Dan Interaksi Perlakuan (BM)

\begin{tabular}{cccccc}
\hline \multirow{2}{*}{ Ektrak Bawang Merah (M) } & \multicolumn{4}{c}{ Biourine Sapi (B) } & \multirow{2}{*}{ Rata-Rata } \\
\cline { 2 - 5 } & $\mathrm{b} 0$ & $\mathrm{~b} 1$ & $\mathrm{~b} 2$ & $\mathrm{~b} 3$ & \\
\hline $\mathrm{m} 0$ & $2,27 \mathrm{e}$ & $3,90 \mathrm{c}$ & $4,30 \mathrm{~b}$ & $2,00 \mathrm{f}$ & $3,95 \mathrm{~b}$ \\
$\mathrm{~m} 1$ & $3,40 \mathrm{~d}$ & $3,90 \mathrm{c}$ & $4,43 \mathrm{~b}$ & $5,47 \mathrm{a}$ & $4,30 \mathrm{a}$ \\
$\mathrm{m} 2$ & $3,43 \mathrm{~d}$ & $3,80 \mathrm{c}$ & $4,40 \mathrm{~b}$ & $5,50 \mathrm{a}$ & $4,28 \mathrm{a}$ \\
$\mathrm{m} 3$ & $3,27 \mathrm{~d}$ & $3,90 \mathrm{c}$ & $4,43 \mathrm{~b}$ & $5,53 \mathrm{a}$ & $4,28 \mathrm{a}$ \\
\hline Rata-Rata & $3,09 \mathrm{~d}$ & $3,87 \mathrm{c}$ & $4,39 \mathrm{~b}$ & $5,46 \mathrm{a}$ & \\
\hline
\end{tabular}

Keterangan : Angka rata-rata yang diikuti dengan huruf yang sama menunjukkan tidak berbeda nyata pada taraf Uji BNT 5\% (BNT b =0,16, $\mathrm{m}=0,16, \mathrm{bm}=0,33)$ 
J. Agrifarm : Vol. 7 No. 2, Desember 2018 P- ISSN : 2301 - 9700, E- ISSN : 25408892

Tabel 2. Rata-Rata Tinggi Tanaman Umur 14 HST Pada Perlakuan Biourine Sapi (B), Ekstrak Bawang Merah (M) Dan Interaksi Perlakuan (BM)

\begin{tabular}{cccccc}
\hline \multirow{2}{*}{ Ektrak Bawang Merah (M) } & \multicolumn{4}{c}{ Biourine Sapi (B) } & Rata-Rata \\
\cline { 2 - 5 } & $\mathrm{b} 0$ & $\mathrm{~b} 1$ & $\mathrm{~b} 2$ & $\mathrm{~b} 3$ & \\
\hline $\mathrm{m} 0$ & $4,27 \mathrm{e}$ & $5,90 \mathrm{c}$ & $6,30 \mathrm{~b}$ & $6,33 \mathrm{~b}$ & $5,95 \mathrm{~b}$ \\
$\mathrm{~m} 1$ & $5,40 \mathrm{~d}$ & $5,90 \mathrm{c}$ & $6,43 \mathrm{~b}$ & $7,47 \mathrm{a}$ & $6,30 \mathrm{a}$ \\
$\mathrm{m} 2$ & $5,43 \mathrm{~d}$ & $5,80 \mathrm{c}$ & $6,40 \mathrm{~b}$ & $7,50 \mathrm{a}$ & $6,28 \mathrm{a}$ \\
$\mathrm{m} 3$ & $5,27 \mathrm{~d}$ & $5,90 \mathrm{c}$ & $6,43 \mathrm{~b}$ & $7,53 \mathrm{a}$ & $6,28 \mathrm{a}$ \\
\hline Rata-Rata & $5,09 \mathrm{~d}$ & $5,88 \mathrm{c}$ & $6,39 \mathrm{~b}$ & $7,46 \mathrm{a}$ & \\
\hline
\end{tabular}

Keterangan : Angka rata-rata yang diikuti dengan huruf yang sama menunjukkan tidak berbeda nyata pada taraf Uji BNT $5 \%(B N T b=0,16, m=0,16, b m=0,33)$

Tabel 3. Rata-Rata Tinggi Tanaman Umur 21 HST Pada Perlakuan Biourine Sapi (B), Ekstrak Bawang Merah (M) Dan Interaksi Perlakuan (BM)

\begin{tabular}{cccccc}
\hline \multirow{2}{*}{ Ektrak Bawang Merah (M) } & \multicolumn{4}{c}{ Biourine Sapi (B) } & \multirow{2}{*}{ Rata-Rata } \\
\cline { 2 - 4 } & $\mathrm{b} 0$ & $\mathrm{~b} 1$ & $\mathrm{~b} 2$ & $\mathrm{~b} 3$ & \\
\hline $\mathrm{m} 0$ & 5,27 & 6,90 & 7,30 & 8,33 & 6,95 \\
$\mathrm{~m} 1$ & 5,40 & 6,90 & 7,43 & 8,47 & 7,05 \\
$\mathrm{~m} 2$ & 6,43 & 6,80 & 7,40 & 8,50 & 7,28 \\
m3 & 6,27 & 6,90 & 7,43 & 8,53 & 7,28 \\
\hline Rata-Rata & $5,84 \mathrm{~d}$ & $6,88 \mathrm{c}$ & $7,39 \mathrm{~b}$ & $8,46 \mathrm{a}$ & \\
\hline
\end{tabular}

Keterangan : Angka rata-rata yang diikuti dengan huruf yang sama menunjukkan tidak berbeda nyata pada taraf Uji BNT 5\% (BNT b =0,45)

Tabel 4. Rata-Rata Tinggi Tanaman Umur 28 HST Pada Perlakuan Biourine Sapi (B), Ekstrak Bawang Merah (M) Dan Interaksi Perlakuan (BM)

\begin{tabular}{cccccc}
\hline \multirow{2}{*}{ Ektrak Bawang Merah (M) } & \multicolumn{4}{c}{ Biourine Sapi (B) } & Rata-Rata \\
\cline { 2 - 5 } & $\mathrm{b} 0$ & $\mathrm{~b} 1$ & $\mathrm{~b} 2$ & $\mathrm{~b} 3$ & \\
\hline $\mathrm{m} 0$ & $7,27 \mathrm{e}$ & $8,90 \mathrm{c}$ & $9,30 \mathrm{~b}$ & $9,33 \mathrm{~b}$ & $8,95 \mathrm{~b}$ \\
$\mathrm{~m} 1$ & $8,40 \mathrm{~d}$ & $8,90 \mathrm{c}$ & $9,43 \mathrm{~b}$ & $10,47 \mathrm{a}$ & $9,30 \mathrm{a}$ \\
$\mathrm{m} 2$ & $8,43 \mathrm{~d}$ & $8,80 \mathrm{c}$ & $9,40 \mathrm{~b}$ & $10,53 \mathrm{a}$ & $9,29 \mathrm{a}$ \\
m3 & $8,27 \mathrm{~d}$ & $8,90 \mathrm{c}$ & $9,43 \mathrm{~b}$ & $10,53 \mathrm{a}$ & $9,28 \mathrm{a}$ \\
\hline Rata-Rata & $8,09 \mathrm{~d}$ & $8,88 \mathrm{c}$ & $9,39 \mathrm{~b}$ & $10,47 \mathrm{a}$ & \\
\hline
\end{tabular}

Keterangan : Angka rata-rata yang diikuti dengan huruf yang sama menunjukkan tidak berbeda nyata pada taraf Uji BNT 5\% (BNT b $=0,16, \mathrm{~m}=0,16, \mathrm{bm}=0,33$ )

Tabel 5. Rata-Rata Tinggi Tanaman Umur 35 HST Pada Perlakuan Biourine Sapi (B), Ekstrak Bawang Merah (M) Dan Interaksi Perlakuan (BM)

\begin{tabular}{|c|c|c|c|c|c|}
\hline \multirow{2}{*}{ Ektrak Bawang Merah (M) } & \multicolumn{4}{|c|}{ Biourine Sapi (B) } & \multirow[t]{2}{*}{ Rata-Rata } \\
\hline & b0 & b1 & b2 & b3 & \\
\hline $\mathrm{m} 0$ & $9,27 \mathrm{e}$ & $10,90 \mathrm{c}$ & $11,30 \mathrm{~b}$ & $11,33 b$ & $10,95 b$ \\
\hline $\mathrm{m} 1$ & $10,40 \mathrm{~d}$ & $10,90 \mathrm{c}$ & $11,43 b$ & $12,47 \mathrm{a}$ & $11,30 \mathrm{a}$ \\
\hline $\mathrm{m} 2$ & $10,43 d$ & $10,80 \mathrm{c}$ & $11,40 b$ & $12,53 \mathrm{a}$ & $11,29 a$ \\
\hline $\mathrm{m} 3$ & $10,27 d$ & $10,90 \mathrm{c}$ & $11,43 b$ & $12,53 \mathrm{a}$ & $11,28 \mathrm{a}$ \\
\hline Rata-Rata & $10,09 \mathrm{~d}$ & $10,88 \mathrm{c}$ & $11,39 b$ & $12,47 \mathrm{a}$ & \\
\hline
\end{tabular}

Keterangan : Angka rata-rata yang diikuti dengan huruf yang sama menunjukkan tidak berbeda nyata pada taraf Uji BNT 5\% (BNT b =0,17, $\mathrm{m}=0,17 \mathrm{bm}=0,33)$

Tabel 6. Rata-Rata Tinggi Tanaman Umur 42 HST Pada Perlakuan Biourine Sapi (B), Ekstrak Bawang Merah (M) Dan Interaksi Perlakuan (BM)

\begin{tabular}{|c|c|c|c|c|c|}
\hline \multirow{2}{*}{ Ektrak Bawang Merah (M) } & \multicolumn{4}{|c|}{ Biourine Sapi (B) } & \multirow[t]{2}{*}{ Rata-Rata } \\
\hline & $\mathrm{b} 0$ & b1 & $\mathrm{b} 2$ & b3 & \\
\hline $\mathrm{m} 0$ & $11,27 \mathrm{~h}$ & $12,87 \mathrm{efg}$ & $13,30 \mathrm{cde}$ & $13,53 b$ & $12,99 \mathrm{c}$ \\
\hline $\mathrm{m} 1$ & $12,40 \mathrm{~g}$ & $12,90 \mathrm{def}$ & $13,37 \mathrm{~cd}$ & $14,43 \mathrm{a}$ & $13,28 b$ \\
\hline $\mathrm{m} 2$ & $12,43 \mathrm{fg}$ & $13,00 \mathrm{de}$ & $13.67 \mathrm{bc}$ & $14,50 \mathrm{a}$ & $13,40 \mathrm{ab}$ \\
\hline $\mathrm{m} 3$ & $12,50 \mathrm{fg}$ & $13,30 \mathrm{cde}$ & $14,13 \mathrm{ab}$ & $14,53 \mathrm{a}$ & $13,62 \mathrm{a}$ \\
\hline Rata-Rata & $12,15 \mathrm{~d}$ & $13,07 \mathrm{c}$ & $13,62 b$ & $14,50 \mathrm{a}$ & \\
\hline
\end{tabular}

Keterangan : Angka rata-rata yang diikuti dengan huruf yang sama menunjukkan tidak berbeda nyata pada taraf Uji BNT 5\% (BNT b $=0,23, \mathrm{~m}=0,23, \mathrm{bm}=0,47)$ 
J. Agrifarm : Vol. 7 No. 2, Desember 2018 P- ISSN : 2301 - 9700, E- ISSN : 25408892

Tabel 7. Rata-Rata Jumlah Daun Umur 7 HST Pada Perlakuan Biourine Sapi (B), Ekstrak Bawang Merah (M) Dan Interaksi Perlakuan (BM)

\begin{tabular}{cccccc}
\hline \multirow{2}{*}{ Ektrak Bawang Merah (M) } & \multicolumn{4}{c}{ Biourine Sapi (B) } & Rata-Rata \\
\cline { 2 - 4 } & $\mathrm{b} 0$ & $\mathrm{~b} 1$ & $\mathrm{~b} 2$ & $\mathrm{~b} 3$ & \\
\hline $\mathrm{m} 0$ & 1,00 & 1,67 & 2,00 & 2,00 & 1,67 \\
$\mathrm{~m} 1$ & 1,00 & 1,67 & 1,67 & 2,00 & 1,58 \\
$\mathrm{~m} 2$ & 1,00 & 1,33 & 1,67 & 2,00 & 1,50 \\
$\mathrm{~m} 3$ & 1,00 & 1,33 & 1,67 & 2,00 & 1,50 \\
\hline Rata-Rata & $1,00 \mathrm{c}$ & $1,50 \mathrm{~b}$ & $1,75 \mathrm{ab}$ & $2,00 \mathrm{a}$ & \\
\hline
\end{tabular}

Keterangan : Angka rata-rata yang diikuti dengan huruf yang sama menunjukkan tidak berbeda nyata pada taraf Uji BNT 5\% (BNT b =0,31)

Tabel 8. Rata-Rata Jumlah Daun Umur 21 HST Pada Perlakuan Biourine Sapi (B), Ekstrak Bawang Merah (M) Dan Interaksi Perlakuan (BM)

\begin{tabular}{cccccc}
\hline \multirow{2}{*}{ Ektrak Bawang Merah (M) } & \multicolumn{4}{c}{ Biourine Sapi (B) } & \multirow{2}{*}{ Rata-Rata } \\
\cline { 2 - 5 } & $\mathrm{b} 0$ & $\mathrm{~b} 1$ & $\mathrm{~b} 2$ & $\mathrm{~b} 3$ & \\
\hline $\mathrm{m} 0$ & 4,00 & 4,67 & 6,00 & 6,00 & 5,17 \\
$\mathrm{~m} 1$ & 4,00 & 4,67 & 5,67 & 6,00 & 5,08 \\
$\mathrm{~m} 2$ & 4,00 & 4,33 & 5,67 & 6,33 & 5,08 \\
$\mathrm{~m} 3$ & 4,00 & 4,33 & 5,67 & 6,00 & 5,00 \\
\hline Rata-Rata & $4,00 \mathrm{~b}$ & $4,50 \mathrm{~b}$ & $5,75 \mathrm{a}$ & $6,08 \mathrm{a}$ & \\
\hline
\end{tabular}

Keterangan : Angka rata-rata yang diikuti dengan huruf yang sama menunjukkan tidak berbeda nyata pada taraf Uji BNT 5\% (BNT b =0,89)

Tabel 9. Rata-Rata Jumlah Daun Umur 28 HST Pada Perlakuan Biourine Sapi (B), Ekstrak Bawang Merah (M) Dan Interaksi Perlakuan (BM)

\begin{tabular}{cccccc}
\hline \multirow{2}{*}{ Ektrak Bawang Merah (M) } & \multicolumn{4}{c}{ Biourine Sapi (B) } & \multirow{2}{*}{ Rata-Rata } \\
\cline { 2 - 5 } & $\mathrm{b} 0$ & $\mathrm{~b} 1$ & $\mathrm{~b} 2$ & $\mathrm{~b} 3$ & \\
\hline $\mathrm{m} 0$ & 6,00 & 6,67 & 7,00 & 7,00 & 6,67 \\
$\mathrm{~m} 1$ & 6,00 & 6,67 & 6,67 & 7,00 & 6,58 \\
$\mathrm{~m} 2$ & 6,00 & 6,33 & 6,67 & 7,33 & 6,58 \\
$\mathrm{~m} 3$ & 6,00 & 6,33 & 6,67 & 7,00 & 6,50 \\
\hline Rata-Rata & $6,00 \mathrm{c}$ & $6,50 \mathrm{~b}$ & $6,75 \mathrm{ab}$ & $7,08 \mathrm{a}$ & \\
\hline
\end{tabular}

Keterangan : Angka rata-rata yang diikuti dengan huruf yang sama menunjukkan tidak berbeda nyata pada taraf Uji BNT 5\% (BNT b =0,34)

Tabel 10. Rata-Rata Jumlah Daun Umur 35 HST Pada Perlakuan Biourine Sapi (B), Ekstrak Bawang Merah (M) Dan Interaksi Perlakuan (BM)

\begin{tabular}{|c|c|c|c|c|c|}
\hline \multirow{2}{*}{ Ektrak Bawang Merah (M) } & \multicolumn{4}{|c|}{ Biourine Sapi (B) } & \multirow[t]{2}{*}{ Rata-Rata } \\
\hline & b0 & b1 & b2 & b3 & \\
\hline $\mathrm{m} 0$ & 8,00 & 8,67 & 9,00 & 9,00 & 8,67 \\
\hline $\mathrm{m} 1$ & 8,00 & 8,67 & 8,67 & 9,00 & 8,58 \\
\hline $\mathrm{m} 2$ & 8,00 & 8,33 & 8,67 & 9.33 & 8,58 \\
\hline m3 & 8,00 & 8,33 & 8,67 & 9,00 & 8,50 \\
\hline Rata-Rata & $8,00 \mathrm{c}$ & $8,50 \mathrm{~b}$ & $8,75 \mathrm{ab}$ & $9,08 \mathrm{a}$ & \\
\hline
\end{tabular}

Keterangan : Angka rata-rata yang diikuti dengan huruf yang sama menunjukkan tidak berbeda nyata pada taraf Uji BNT 5\% (BNT b =0,34)

Tabel 11. Rata-Rata Jumlah Daun Umur 42 HST Pada Perlakuan Biourine Sapi (B), Ekstrak Bawang Merah (M) Dan Interaksi Perlakuan (BM)

\begin{tabular}{cccccc}
\hline \multirow{2}{*}{ Ektrak Bawang Merah (M) } & \multicolumn{4}{c}{ Biourine Sapi (B) } & Rata-Rata \\
\cline { 2 - 4 } & $\mathrm{b} 0$ & $\mathrm{~b} 1$ & $\mathrm{~b} 2$ & $\mathrm{~b} 3$ & \\
\hline $\mathrm{m} 0$ & 8,00 & 9,00 & 9,00 & 11,00 & 9,25 \\
$\mathrm{~m} 1$ & 8,00 & 9,00 & 9,00 & 11,67 & 9,42 \\
$\mathrm{~m} 2$ & 8,00 & 9,00 & 9,00 & 13,00 & 9,75 \\
m3 & 8,00 & 9,67 & 9,00 & 13,00 & 9,92 \\
\hline Rata-Rata & $8,00 \mathrm{c}$ & $9,17 \mathrm{~b}$ & $9,00 \mathrm{~b}$ & $12,17 \mathrm{a}$ & \\
\hline
\end{tabular}

Keterangan : Angka rata-rata yang diikuti dengan huruf yang sama menunjukkan tidak berbeda nyata pada taraf Uji BNT 5\% (BNT b $=0,61$ ) 
Tabel 12. Rata-Rata Hari Bentuk Krop Pada Perlakuan Biourine Sapi (B), Ekstrak Bawang Merah (M) Dan Interaksi Perlakuan (BM)

\begin{tabular}{|c|c|c|c|c|c|}
\hline \multirow{2}{*}{ Ektrak Bawang Merah (M) } & \multicolumn{4}{|c|}{ Biourine Sapi (B) } & \multirow[t]{2}{*}{ Rata-Rata } \\
\hline & b0 & b1 & $\mathrm{b} 2$ & b3 & \\
\hline $\mathrm{m} 0$ & $48,33 a$ & $47,67 \mathrm{abc}$ & $47,67 \mathrm{abc}$ & $41,67 \mathrm{e}$ & $46,57 \mathrm{a}$ \\
\hline $\mathrm{m} 1$ & $48,33 \mathrm{a}$ & $48,33 \mathrm{a}$ & $47,67 \mathrm{abc}$ & $42,00 \mathrm{e}$ & $46,58 \mathrm{a}$ \\
\hline $\mathrm{m} 2$ & 48,00ab & $46,67 b c$ & $46,33 c$ & $41,67 \mathrm{e}$ & $45,67 b$ \\
\hline $\mathrm{m} 3$ & $48,33 \mathrm{a}$ & $47,67 \mathrm{abc}$ & $44,00 \mathrm{~d}$ & $42,33 \mathrm{e}$ & $45,58 \mathrm{~b}$ \\
\hline Rata-Rata & $48,25 \mathrm{a}$ & $47,58 \mathrm{a}$ & $46,42 b$ & $41,92 \mathrm{c}$ & \\
\hline
\end{tabular}

Keterangan : Angka rata-rata yang diikuti dengan huruf yang sama menunjukkan tidak berbeda nyata pada taraf Uji BNT $5 \%($ BNT $\mathrm{b}=0,77, \mathrm{~m}=0,77, \mathrm{bm}=1,54)$

Tabel 13. Rata-Rata Berat Krop Pada Perlakuan Biourine Sapi (B), Ekstrak Bawang Merah (M) Dan Interaksi Perlakuan (BM)

\begin{tabular}{cccccc}
\hline \multirow{2}{*}{ Ektrak Bawang Merah (M) } & \multicolumn{4}{c}{ Biourine Sapi (B) } & \multirow{2}{*}{ Rata-Rata } \\
\cline { 2 - 5 } & $\mathrm{b} 0$ & $\mathrm{~b} 1$ & $\mathrm{~b} 2$ & $\mathrm{~b} 3$ & \\
\hline $\mathrm{m} 0$ & 514,67 & 529,67 & 598,73 & 603,67 & $561,68 \mathrm{~b}$ \\
$\mathrm{~m} 1$ & 511,70 & 531,13 & 585,67 & 605,00 & $558,38 \mathrm{~b}$ \\
$\mathrm{~m} 2$ & 520.07 & 541,83 & 600,67 & 606,00 & $567,14 \mathrm{ab}$ \\
$\mathrm{m} 3$ & 542,00 & 554,77 & 601,23 & 605,73 & $577,93 \mathrm{a}$ \\
Rata-Rata & $522,10 \mathrm{c}$ & $539,35 \mathrm{~b}$ & $596,58 \mathrm{a}$ & $605,10 \mathrm{a}$ & \\
\hline
\end{tabular}

Keterangan : Angka rata-rata yang diikuti dengan huruf yang sama menunjukkan tidak berbeda nyata pada taraf Uji BNT $5 \%($ BNT $\mathrm{b}=10,55, \mathrm{~m}=10,55)$

Tabel 14. Rata-Rata Diameter Krop Pada Perlakuan Biourine Sapi (B), Ekstrak Bawang Merah (M) Dan Interaksi Perlakuan (BM)

\begin{tabular}{|c|c|c|c|c|c|}
\hline \multirow{2}{*}{ Ektrak Bawang Merah (M) } & \multicolumn{4}{|c|}{ Biourine Sapi (B) } & \multirow[t]{2}{*}{ Rata-Rata } \\
\hline & b0 & b1 & $\mathrm{b} 2$ & b3 & \\
\hline $\mathrm{m} 0$ & 7,33 & 8,63 & 11,67 & 14,40 & $10,51 b$ \\
\hline $\mathrm{m} 1$ & 7,60 & 9,30 & 12,60 & 15,37 & $11,22 b$ \\
\hline $\mathrm{m} 2$ & 9,20 & 10,30 & 12,60 & 17,67 & $12,44 \mathrm{a}$ \\
\hline $\mathrm{m} 3$ & 8,67 & 10,53 & 13,03 & 16,73 & $12,24 \mathrm{a}$ \\
\hline Rata-Rata & $8,20 \mathrm{~d}$ & $9,69 \mathrm{c}$ & $12,48 b$ & $16,04 \mathrm{a}$ & \\
\hline
\end{tabular}

Keterangan : Angka rata-rata yang diikuti dengan huruf yang sama menunjukkan tidak berbeda nyata pada taraf Uji BNT 5\% (BNT b $=0,75, \mathrm{~m}=0,75$ )

\section{Pengaruh Perlakuan Biourine Sapi Terhadap Tanaman Kubis}

Berdasarkan hasil sidik ragam perlakuan dosis biourine sapi berpengaruh sangat nyata terhadap parameter tinggi tanaman dan jumlah daun umur 7 hst, 14 hst, 21 hst, 28 hst,35 hst dan 42 hst, hari bentuk krop, berat krop dan diameter krop. Hasil uji BNT 5\% menunjukkan bahwa taraf $\mathrm{b} 3$ berbeda nyata terhadap taraf b0, b1 dan b2 para parameter tinggi tanaman umur $7 \mathrm{hst}, 14$ hst, 21 hst, 35 hst, 42 hst, jumlah daun umur 42 hst, hari bentuk krop dan diameter krop. Namun tidak berbeda nyata terhadap taraf b2 pada parameter jumlah daun umur 7 hst, 14 hst, 21 hst, 28 hst, 35 hst dan berat krop.

Hasil uji BNT 5\% menunjukkan bahwa taraf b3 merupakan perlakukan yang memberikan pengaruh tertinggi para parameter tinggi tanaman umur 7 hst, 14 hst, 21 hst, 35 hst, 42 hst, jumlah daun umur 42 hst. Berbedanya pertumbuhan vegetatif dan generatif tanaman kubis hal ini sesuai dengan tulisan Lingga dan
Marsono (2013) mengenai pemberian dosis pupuk pada tanaman akan memberikan pengaruh terhadap pertumbuhan vegetatif dan generatif tanaman. Hal juga diduga bahwa biourine sapi yang mempunyai kadar $\mathrm{N}$ $0,5240 \%$ memberikan pengaruh pada pertumbuhan vegetatif. Hal ini sesuai dengan pendapat Sutedjo (2008) bahwa nitrogen merupakan unsur hara utama bagi pertumbuhan tanaman yang pada umumnya sangat diperlukan untuk pembentukan atau pertumbuhan vegetatif tanaman seperti daun, batang dan akar.

\section{Pengaruh Perlakuan Ekstrak Bawang Merah Terhadap Tanaman Kubis}

Berdasarkan hasil sidik ragam perlakuan dosis biourine sapi berpengaruh sangat nyata terhadap parameter tinggi tanaman dan jumlah daun umur 7 hst, 14 hst, 28 hst, 35 hst dan 42 hst, hari bentuk krop, berat krop dan diameter krop. Hasil uji BNT 5\% menunjukkan bahwa taraf m0 berbeda nyata terhadap taraf $\mathrm{m} 1, \mathrm{~m} 2$ dan $\mathrm{m} 3$ 
pada parameter tinggi tanaman umur 7 hst, 14 hst, 35 hst, 42 hst, hari bentuk krop dan diameter krop. Namun tidak berbeda nyata terhadap taraf $\mathrm{m} 2$ pada parameter tinggi tanaman umur 42 hst, hari krop, berat krop dan diameter krop.

Hasil uji BNT 5\% menunjukkan bahwa taraf m1 merupakan perlakukan yang memberikan pengaruh tertinggi para parameter tinggi tanaman umur 7 hst, 14 hst, 35 hst, 42 hst. Hasil uji BNT 5\% pada parameter hari bentuk krop tercepat pada taraf $\mathrm{m} 2$ dan $\mathrm{m} 3$, berat krop terberat pada taraf $m 2$ dan $m 3$ dan diameter krop menunjukkan bahwa taraf $\mathrm{m} 2$ dan $\mathrm{m} 3$. Hal ini terjadi diduga bahwa karena kandungan ekstrak bawang merah IAA 3,8254 ppm , Giberelin 85,2083 ppm dan Kinetin 21, 8178 ppm yang mampu merangsang pertumbuhan akar dan vitamin B1 (thiamin) yang berperan penting dalam proses perombakan karbohidrat menjadi energi dalam metabolisme tanaman. (Siti Masitoh, 2016).

\section{Pengaruh Kombinai Perlakuan Biourine Sapi dan Ekstrak Bawang Merah Terhadap Tanaman Kubis}

Hasil sidik ragam bahwa kombinasi perlakuan biourine sapi dan ekstrak bawang merah terhadap tanaman kubis menunjukkan bahwa taraf b3m1, b3m2 dan b3m3 berbeda nyata terhadap taraf yang lainnya pada parameter tinggi tanaman umur $7 \mathrm{hst}, 14 \mathrm{hst}, 21$ hst, 28 hst, 35 hst dan 42 hst serta hari terbentuk krop. Hal membuktikan bahwa biourine sapi dan

\section{KESIMPULAN}

1. Biourine sapi mempengaruhi tinggi tanaman, jumlah daun pada umur 7, 14, 21, 28,35 dan 42 hst. Berat krop dengan hasil terbaik pada taraf b2 (75\% biourine sapi) dengan Berat 596,58 gram.

2. Ekstrak bawang merah mempengaruhi tinggi tanaman, jumlah daun pada umur 7, 14, 21, 28,35 dan 42 hst, Berat krop dengan hasil terbaik pada taraf $\mathrm{m} 2$ (75\% ekstrak bawang merah) dengan Berat 567,14 gram.

3. Interkasi perlakuan biourine sapi dan bawang merah mempengaruhi tinggi tanaman, jumlah daun pada umur 7, 14, 21, 28,35 dan 42 hst dan hari terbentuk krop pada taraf b2 $\mathrm{m} 2$ (75\% biourine sapi dan 75 ekstrak bawang merah).

\section{UCAPAN TERIMA KASIH}

Terima kasih kepada Universitas Widya Gama Mahakam yang telah membiayai penelitian ini. ekstrak bawang merah mempengaruhi tinggi tanaman umur 7 hst, 14 hst, 21 hst, 28 hst, 35 hst dan 42 hst serta hari terbentuk krop karena masing-masing kandungan yang dimiliki. Biourine mempunyai unusr $\mathrm{N}$ sesuai dengan pendapat Sutedjo (2008) bahwa nitrogen merupakan unsur hara utama bagi pertumbuhan tanaman yang pada umumnya sangat diperlukan untuk pembentukan atau pertumbuhan vegetatif tanaman seperti daun, batang dan akar. Ekstrak bawang merah mempunyai IAA 3,8254 ppm , Giberelin 85,2083 ppm dan Kinetin 21, 8178 ppm yang mampu merangsang pertumbuhan akar dan vitamin B1 (thiamin) yang berperan penting dalam proses perombakan karbohidrat menjadi energi dalam metabolisme tanaman. (Siti Masitoh, 2016). Berat dan diameter krop yang tidak berbeda nyata keadaaa ini menunjukkan bahwa antara perlakuan biourine sapi dan ekstrak bawang merah secara bersamasama dalam mempengaruhi kedua faktor perlakuan tersebut memberikan pengaruh secara terpisah dan bertindak bebas satu terhadap lainnya. Seperti yang dikemukan oleh Gomez dan Gomez (1995), bahwa dua faktor dikatakan berinteraksi apabila pengaruh suatu faktor perlakuan berubah pada saat perubahan taraf faktor perlakuan lainnya. Selanjutnya dinyatakan oleh Steel dan Torrie (1991), bahwa bila pengaruh interaksi berbeda tidak nyata maka disimpulkan bahwa diantara faktor perlakuan tersebut bertindak bebas satu sama lainnya.

\section{DAFTAR PUSTAKA}

Anonim. 2016. Laporan Kerja Badan Penelitian dan Pengembangan Penelitian Kementerian Pertanian. Badan Penelitian dan Pengembangan Penelitian Kementerian Pertanian. Jakarta.

Bilad. MR. 2011. Biourine atau Urine Sebagai Pupuk Organik Cair. Alternatif Yang Lebih Baik. http://www.Sasak.Org. Diakases Tanggal 1 September 2018.

BPS.2017.htpp://kaltim.bps.go.id/statictable/201 5/03/10/38/produksi-buah-buahan-menurutjenisnya-ton-tahun2011-2015-.html. Diakses 1 September 2018.

Erwin, Nur, Muhammad Asfian, Panggabean, A. Sentosa. 2015. Potensi Pemanfaatan Ekstrak Kubis Unggu (Brassica oleracea L) sebagai Indikator Asam Basa Alami. Kimia FMIPA Unmul Kimia FMIPA Unmul 
Jurusan Kimia FMIPA. Universitas Mulawarman. Samarinda.

Gomez, K.A dan A.A Gomez. 1995. Prosedur Statistika untuk Penelitian Pertanian (Terjemahan A. Sjamsuddin \& J.S Baharsyah). Edisi Kedua. UI Press. Jakarta.

Hanafiah, Kemas Ali. 2005. Rancangan Percobaan. PT. RajaGrafindo. Jakarta.

Hariyah. A. 2008. Pengaruh Dosis dan Interval Pemupukan Biourine Sapi Terhadap Pertumbuhan dan Hasil Cabai Besar Var. Hot Beauty (Capsicum annuum L). Fakultas Pertanian Universitas Mulawarman. Samarinda.

Husein, E., Saraswati. R. 2010. Rhizobakteri Pemacu Tumbuh Tanaman. Pupuk Organik dan dan Pupuk Hayati. 191 -209.

Irawati. Syfandy. 2017. Pengaruh Ekstrak Limbah Bawang Merah (Alium cepa L). Terhadap Pertumbuhan Tanaman Sawi (Brassica juncea L) Secara Hidroponik sebagai Penunjang Praktikum Mata Kuliah Fisiologi Tumbuhan. Thesis. Universitas Islam Ar-Raniry Banda Aceh. Aceh.

Marsono dan Lingga, Pinus. 2006. Petunjuk Penggunaan Pupuk. Penebar Swadaya. Jakarta.

Pranata, A. S. 2004. Meningkatkan Hasil Panen dengan Pupuk Organik. Agromedia Pustaka. Bogor.

Purwanti, Novi Irma. 2017. Aplikasi Ekstrak Bawang Merah Sebagai Zat Pengatur Tumbuh pada Kedelai Varietas Grobogan. Other Thesis. Universitas Sebelas Maret. Surakarta.

Puspita, Putri Bella. 2015. Pengaruh Biourine Sapi dan Berbagai Dosis $N$ terhadap Tanaman Kailan (Brassica oleraceae L). . Jurnal Produksi Tanaman. Universitas Brawijaya. Malang.

Rukmana, R. 2010. Budidaya Kubis Bunga dan Broccoli. Kanisius. Yogyakarta.

Siti, Masitoh. 2016. Pengaruh Konsentrasi Ekstrak Bawang Merah terhadap Pertumbuhan Stek Batang Buah Naga Merah (Hylocereus costaricensis) (Web.) Britton and Rose. Skripsi Agroteknologi
Fakultas Pertanian Universitas Lampung. Bandar Lampung.

Steel, R. G. D dan J. H. Torrie. 1991. Prinsip dan Prosedur Statistika Suatu Biometric Terjemahan Bambangan Sumantri. Gramedia Pustaka. Jakarta.

Sunarjono. H. H. 2011. Bertanam 30 Jenis Sayur. Penebar Swadaya. Jakarta.

Sutedjo. M. M. 2008. Pupuk dan Cara Pemupukan. Rineka Cipta. Jakarta.

Yuliarta, B. 2014. Pengaruh Biourine Sapid an Berbagai Dosis Pupuk NPK terhadap Pertumbuhan dan Hasil Tanaman Selada Krop (Lactuca sativa L). Jurnal Produksi Tanaman. Universitas Brawijaya. Malang.

Yusrani, Awang dan Subroto. 2005. Kesuburan dan Pemanfaatan Tanah. Banyumedia Pubslishing. Malang. 